\title{
Strategi Humas TVRI Dalam Memperbaiki Citra TVRI Di Mata Publik
}

\author{
Wina Puspita Sari \\ Indah Nursyamsiah
}

\begin{abstract}
TVRI is the oldest public station to in Indonesia. Nowadays, TVRI has many competitors such as several national station to and cable tv. Slowly but sure, TVRI left by it audiences. The current image of TVRI is out of date and the program is un interesting to see so that public relations officers of TVRI have to do some strategy to fix their image in order to have their audience back.
\end{abstract}

Keyword :Public Relations Strategy, Image

\section{Latar Belakang}

Televisi Republik Indonesia (TVRI) sebagai stasiun televisi milik negara merupakan yang pertama di dunia pertelevisian. Namun ditengah maraknya stasiun tv swasta dan lokal, keberadaan TVRI sebagai televisi milik negara kian ditinggalkan pemirsanya. Hal ini dapat di lihat pada kutipan berita dari sebagai berikut ${ }^{1}$

Diusia tuanya TVRI semakin ditinggalkan pemirsa dipandang sangat menghawatirkan lagi, kondisi seperti ini terjadi pula pada hampir setiap daerah yang dikelola TVRI berbagai paket andalan yang disiapkan untuk keragaman budaya masing-masing daerah tampaknya belum banyak dilirik oleh pemirsa daerah. Terbukti, melalui hasil survei ini tidak lebih dari $10 \%$ responden yang mengaku menonton tayangan daerah masing-masing wilayah. Semua hasil survei diatas semakin menegaskan bahwa televisi

\footnotetext{
${ }^{1}$ http: //www.kompasonline.com,02/11/08,09.00//
} 
swasta telah merebut waktu dan kebutuhan sebagian besar masyarakat di 10 kota besar itu. Hasil penelitian ini mengungkapkan dua alasan besar mengapa masyarakat beralih dari TVRI. Ada dua alasan mengapa masyarakat beralih dari TVRI yaitu; (1) menyangkut kemasan program tayangan. Bagi sebagian besar pemirsa televisi, kemasan acara yang ditampilkan stasiun ini dianggap ketinggalan zaman. Mereka menilai mulai dari penataan panggung, pencahayaan, sudut pengambilan gambar, hingga materi acara yang ditampilkan kurang menarik selera untuk menontonnya. (2) Menyangkut masalah teknis. Menurut sebagian responde, di Jakarta, Bandung, Bandar Lampung, Makasar, penerimaan gambar stasiun televisi ini sangat buruk. Kadang kala hanya terdengar suara saja atau gambar yang tidak terlalu jelas. Dengan situasi seperti ini, kalau tidak terpaksa maka stasiun televis ini jarang diniknati. Dengan adanya kedua alasan tersebut tampaknya berkaitan dengan konteks keberadaan TVRI saat ini.

Dengan demikian, hal ini merupakan tugas dari humas TVRI, yakin memperbaiki citra TVRI yang saat ini mulai menurun dan merosot dimata publik. Hal inilah yang melatarbelakangi penulis mengajukan riset dan mengambil judul "Strategi humas TVRI dalam memperbaiki citra TVRI dimata publik (penonton)".

\section{Strategi Humas (Public Relations)}

Menurut Zulkarmein strategi ialah "cara-cara atau langkah-langkah yang dirancang untuk mencapai tujuan yang dirumuskan. Biasanya strategi berorientasi kepada hasil efek yang hendak dicapai". (Zulkarmein,1998:181). Landasan umum dalam proses penyusunan strategi public relations, menurut Ahmad S. Adnanputra dalam makalah " $P R$ Strategy, yang berkaitan dengan fungsi-fungsi PR atau Humas secara integral melekat pada manajemen suatu perusahaan atau lembaga, yaitu sebagai berikut : 
1. Mengidentifikasi permasalahan yang muncul.

2. Identifikasi unit-unit sasarannya.

3. Mengevaluasi mengenai pola dan kadar sikap tindak unit sebagai sasarannya.

4. Mengidentifikasi tentang struktur kekuasaan pada unit sasaran.

5. Pemilihan opsi atau unsur taktikal strategi public relations.

6. Mengidentifikasi dan evaluasi terhadap perubahan kebijakan sasaran atau peraturan pemerintahan dan lain sebagainya.

7. Langkah terakhir adalah menjabarkan strategi public relations, dan taktik atau cara menerapkan langkah-langkah program yang telah direncanakan, dilaksanakan, mengkomunikasikan, dan penilaian atau evaluasi hasil kerja. (Ruslan,2007:139-140).

Humas berfungsi untuk menciptakan iklim yang kondusif dalam mengembangkan tanggung jawab serta partisipasi antara pejabat Humas atau PRO dan masyarakat (khalayak sebagai sasaran) untuk mewujudkan tujuan bersama. Fungsi tersebut dapat diwujudkan melalui beberapa aspekaspek pendekatan atau strategi humas :

a. Strategi operasional

Melalui pelaksanaan program humas yang dilakukan dengan pendekatan kemasyarakatan (sociologi approach), melalui mekanisme sosial kultural dan nilai-nilai yang berlaku di masyarakat dari opini atau kehendak masyarakat terekam pada setiap berita atau surat pembaca dan lain sebagainya yang dianut di berbagai media massa. Artinya pihak humas mutlak bersikap atau berkemampuan untuk mendengar (listening), dan bukan sekedar mendengar (hear) mengenai aspirasi yang ada di dalam masyarakat, baik mengenai etika, moral maupun nilai-nilai kemasyarakatan yang dianut.

b. Pendekatan persuasif dan edukasif 
Fungsi humas adalah menciptakan komunikasi dua arah (timbal balik) dengan menyebarkan informasi dan organisasi kepada pihak publiknya yang bersifat mendidik dan memberikan penerangan, maupun dengan melakukan pendekatan persuasif, agar tercipta saling pengertian, menghargai, pemahaman, toleransi dan lain sebagainya.

c. Pendekatan tanggung jawab sosial humas

Menumbuhkan sikap tanggung jawab sosial bahwa tujuan dan sasaran yang hendak dicapai tersebut bukan ditunjukan untuk mengambil keuntungan sepihak dari publik sasarannya (masyarakat), namun untuk memperoleh keuntungan bersama.

\section{d. Pendekatan kerja sama}

Betapa membina hubungan yang harmonis antara organisasi dengan berbagai kalangan, baik hubungan ke dalam (internal relations) maupun hubungan ke luar (eksternal relations) untuk meningkatkan kerja sama. Humas berkewajiban memasyarakatkan misi instansi yang diwakilinya agar diterima oleh atau mendapat dukungan masyarakat (publik sasaranya). Hal ini dilakukan dalam rangka menyelenggarakan hubungan baik dengan publiknya (community relations), dan untuk memperoleh opini publik serta perbahan sikap yang positif bagi kedua belah pihak (mutual understanding).

e. Pendekatan koordinatif dan integratif

Untuk memperluas peranan PR di masyarakat, maka fungsi humas dalam arti sempit hanya mewakili lembaga atau institusinya. Tetapi peranannya yang lebih luas adalah berpartisipasi dalam menunjang program pembangunan nasional, dan mewujudkan Ketahanan Nasional dibidang politik, ekonomi, sosial budaya (Poleksosbud) dan Hankamnas. (Ruslan,1998:142-144). 
Dalam membuat strategi, humas melakukan langkah atau tahapan strategi komunikasi untuk menyusun strategi komunikasi diperlukan langkahlangkah yang baik antara lain :

1. Mengenal Sasaran

Mengenal sasaran merupakan langkah pertama bagi komunikator dalam usaha komunikasi yang efektif. Dalam proses komunikasi, sasaran itu tidak pasif, melainkan aktif, sehingga antara komuniaktor dan komunikan bukan saja terjadi saling berhubungan, tetapi juga saling mempengaruhi. Artinya sasaran dapat dipengaruhi oleh komunikan atau sasaran. (Arifin,2003:59-78)

2. Menyusun Pesan

Setelah mengenal sasaran, maka langkah selanjutnya perumusan strategi, ialah menyusun pesan yaitu menentukan tema dan materi. Syarat utama dalam mempengaruhi sasaran dari pesan tersebut adalah mampu membangkitkan perhatian. (Arifin,2003:59-78)

Selanjutnya menurut Harwood Childs yang dikutip oleh Rosady Ruslan dalam bukunya kiat dan strategi kampanye public relations, ada beberapa strategi dalam kegiatan Public Relations untuk merancang suatu pesan dalam bentuk informasi atau berita, yaitu sebagai berikut :

\section{a. Strategi of Publicity}

Melakukan kampanye untuk penyebaran pesan atau message melalui proses publikasi suatu berita melalui kerjasama ddengan berbagai media massa. Selain itu dengan mengunakan taktik merekayasa sustu berita akan dapat menarik perhatian audiensi sehingga akan menciptakan publisitas yang menguntungkan.

\section{b. Strategi of Persuations}

Berkampanye untuk membujuk atau menggalang khalayak melalui teknik sugesti atau persuasi untuk mengubah opini publik dengan mengangkat segi emosional dari suatu cerita, artikel berlandaskan humanity interest. 


\section{c. Strategi of Argumentation}

Strategi ini biasanya dipakai untuk mengantisipasi berita negatif yang jarang menguntungkan atau negative news, kemudian dibentuk berita tandingan yang mengemukakan argumentasi yang rasional agar opini publik tetap dalam posisi yang menguntungkan. Dalam hal ini kemampuan Publik Relations sebagai komunikator yang handal diperlukan untuk mengemukakan suatu fakta yang jelas dan rasional dalam mengubah opini publik melalui berita atau statement yang dipublikasikan.

\section{d. Strategi of Image}

Strategi pembentukan berita yang positif dalam publikasi untuk menjaga citra atau organisasi termasuk produknya. Misalnya tidak hanya menapilkan segi promosi, tetapi bagaimana menciptakan publikasi non komersil dan menampilkan kepedulian terhadap lingkungan dan sosial atau Humanity Relations and Sosial Marketing yang menguntungkan citra bagi lembaga atau organisasi secara keseluruhan atau corporate image. (Ruslan,2000:48-49)

\section{Menetapkan Metode}

Metode penyampaian atau mempengaruhi dapat dilihat dari dua aspek, yaitu : menurut cara pelaksanaanya dan menurut bentuk isinya. Menurut cara pelaksanaanya dapat diwujudkan dalam dua bentuk yaitu metode reduandancy (repetition) dan canalizing. Sedangkan yang kedua (menurut bentuk isinya) dikenal metode-metode : informatif, persuasif, edukatif, dan kursif. (Arifin,2003:59-78)

\section{Seleksi dan Penggunaan Media}

Penggunaan medium sebagai alat penyaluran ide, adalah suatu hal yang merupakan keharusan. Sebagaimana dalam menyusun pesan dari suatu komunikasi yang ingin dilancarkan, kita harus selektif, dalam arti menyesuaikan keadaan dan kondisi sasaran, maka dengan sendirinya dalam 
penggunaan mediapun mempunyai kemampuan dan kelemahannya sendiri. (Arifin,2003:59-78)

Klasifikasi media ditentukan berdasarkan kriteria tataran komunikasinya, yaitu :

a. Media Antar Pribadi

Media antar pribadi adalah media komunikasi yang digunakan dalam tataran pribadi. Contohnya : Telepon dan surat.

b. Media Massa

Media masaa adalah media komunikasi yang digunakan dalam tataran massa. Media massa yang utama adalah surat kabar, majalah, radio, televisi, dan film.

Surat kabar dan majalah adalah cetak, radio bersifat audio, sedangkan televisi dan film bersifat audio-visual. Dan media komunikasi yang terbaru adalah internet. (Vardiansyah,2004:102-107).

\section{Citra}

Menurut Bill Canton dalam Sukatendel (1990) mengatakan bahwa citra adalah

"image: the impression, the feeling, the conception which the public has of a company; a concioussly created impression of on object, person or organization"(Citra adalah kesan, perasaan, gambaran dari publik terhadap perusahaan; kesan yang dengan sengaja diciptakan dari suatu obyek, orang atau organisasi). (Soemirat\&Adrianto,2004:111).

Citra adalah tujuan utama, dan sekaligus merupakan reputasi dan prestasi yang hendak dicapai bagi dunia hubungan masyarakat (kehumasan) atau public relations. Penilaian atau tanggapan masyarakat tersebut dapat berkaitan dengan timbulnya rasa hormat (respek), kesan-kesan yang baik dan menguntungkan terhadap suatu citra lembaga atau organisasi atau produk 
barang dan jasa pelayanan yang diwakili oleh pihak humas (PR). (Ruslan,2007:75-76).

\section{Jenis-Jenis Citra}

Menurut Frank Jefkins, dalam bukunya Hubungan Masyarakat, ada beberapa jenis citra (image) yang dikenal di dunia aktivitas hubungan masyarakat (public relations), dan dapat dibedakan satu dengan yang lain sebagai berikut:

\section{a. Citra Cermin (mirror image)}

Pengertian disini bahwa citra cermin yang yakni oleh perusahaan bersangkutan, terutama para pemimpinnya yang selalu merasa dalam posisi baik tanpa mengacuhkan kesan orang luar. Setelah diadakan studi tentang tanggapan, kesan dan citra di masyarakat ternyata terjadi perbedaan antara yang diharapkan dengan kenyataan citra di lapangan, bisa terjadi justru menceminkan "citra" negatifnya yang muncul.

b. Citra kini (current image)

Citra merupakan kesan yang baik diperoleh dari orang lain tentang perusahaan atau organisasi atau hal yang lain berkaitan dengan produknya. Berdasarkan pengalaman dan informasi kurang baik penerimaannya, sehingga dalam posisi tersebut pihak humas (PR) akan menghadapi resiko yang sifatnya permusuhan, kecurigaan, prasangka buruk (prejudice), dan hingga muncul kesahpahaman (misunderstanding) yang menyebabkan citra kini yang ditanggapi secara tidak adil atau bahkan kesan yang negatif diperolehnya.

\section{c. Citra keinginan (wish image)}

Citra keinginan ini adalah seperti apa yang ingin dan dicapai oleh pihak manajemen terhadap lembaga atau perusahaan, atau produk yang ditampilkan tersebut lebih dikenal (good awareness), menyenangkan dan 
diterima dengan kesan yang selalu positif diberikan (take and give) oleh publiknya atau masyarakat umum.

\section{d. Citra perusahaan (corporate image)}

Jenis citra ini adalah yang berkaitan dengan sosok perusahaan sebagai tujuan utamanya, bagaimana menciptakan citra perusahaan (corporate image) yang positif, lebih dikenal serta diterima oleh publiknya, mungkin tentang sejarahnya, kualitas pelayanan prima, keberhasilan dalam bidang marketing, dan hingga berkaitan dengan tanggung jawab sosial (social care) sebagainya. Dalam hal ini publik Humas (PR) berupaya atau bahkan ikut bertanggung jawab untuk mempertahankan citra perusahaan, agar mampu mempengaruhi harga sahamnya tetap bernilai tinggi (liquid) untuk berkompetisi di pasar bursa saham.

e. Citra serbaneka (multiple image)

Citra ini merupakan pelengkap dari citra perusahaan diatas, misalnya bagaimana pihak Humas (PR)-nya akan menampilkan pengenalan (awareness) terhadap identitas perusahaan, atribut logo, brand's name, seragam (uniform) para front liner, sosok gedung, dekorasi lobby kantor dan penampilan para profesionalnya. Semua itu kemudian diunifikasikan atau diidentifikasikan ke dalam suatu citra perusahaan (corporate image)

f. Citra penampilan (perfomance image)

Citra penampilan ini lebih ditunjukan kepada subjeknya, bagaimana kinerja atau penampilan diri (perfomance image) para profesional pada perusahaan bersangkutan. Mungkin masalah citra penampilan kurang diperhatikan atau banyak disepelekan orang. (Ruslan,2007:75-76)

\section{Proses Pembentukan Citra}

Citra terbentuk berdasarkan pengetahuan dan informasi yang diterima seseorang. Komunikasi tidak secara langsung menimbulkan perilaku 
tertentu, tetapi cenderung mempengaruhi cara kita mengorganisasikan citra kita tentang lingkungan.

Proses pembentukan citra dalam struktur kognitif yang sesuai dengan pengertian sistem komunikasi dijelaskan oleh John S. Nipoeno, dalam laporan penelitian tentang Tingakh Laku Konsumen, seperti yang dikutip Danasaputra, sebagai berikut :

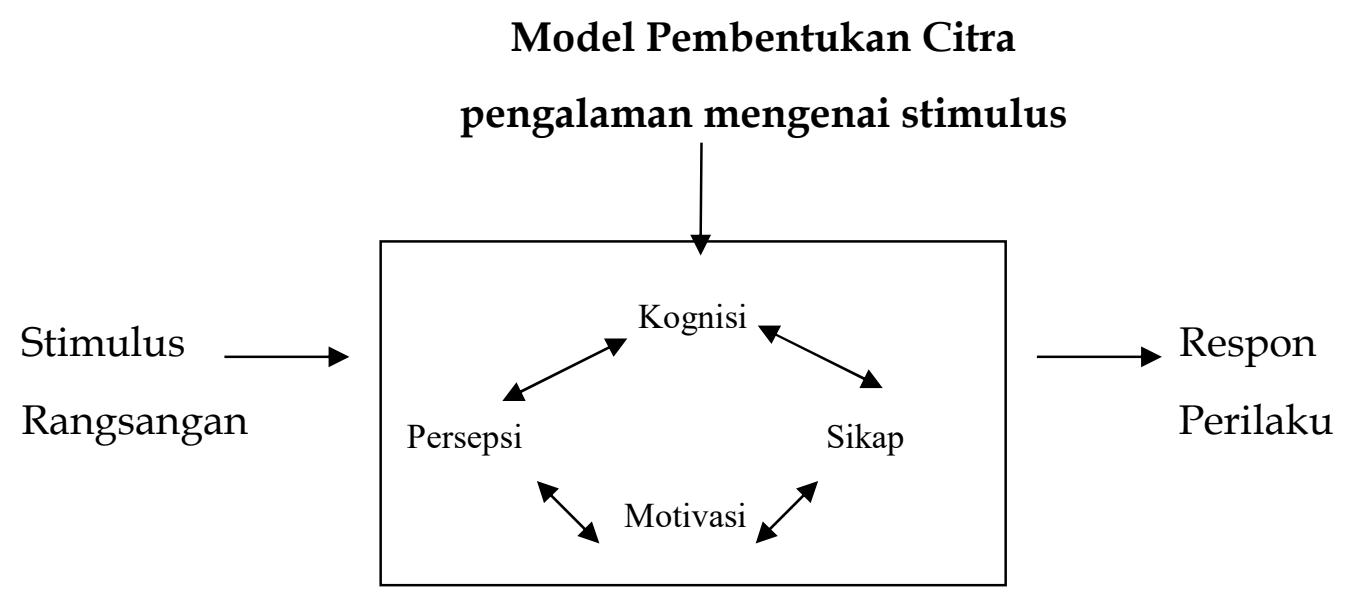

Public Relations digambarkan sebagai input-output, proses intern dalam model ini adalah pembentukan citra, sedangkan input adalah stimulus yang diberikan dan output adalah tanggapan atau perilaku tertentu. Citra itu sendiri digambarkan melalui persepsi kignisi-motivasi-sikap. Model pembentukan citra ini menunjukan bagaimana stimulus yang berasal dari luar dioragnisasikan dam mempengaruhi respons. Stimulus (rangsang) yang diberikan pada individu dapat diterima atau ditolak.

(Soemirat\&Adrianto,2004:114-115).

\section{Definisi Konsep}

Di dalam penelitian konsep-konsep perlu dioperasionalkan. Konsep-konsep yang penulis gunakan di dalam penelitian ini sebagai berikut : 
1. Strategi Humas, adalah Alternatif optimal yang dipilih untuk ditempuh guna mencapai tujuan public relations dalam rangka suatu rencana public relations (public relations plan). Jadi humas TVRI, setiap ingin melakukan sesuatu kegiatan yang sudah dipikiran atau direncanakan oleh Humas TVRI ketika akan melakukan kegiatan agar tujuan yang diinginkan dapat tercapai dan terwujud dengan lancar dan sukses.

2. Citra, adalah kesan yang dirasakan oleh perorangan atau secara kelompok ataupun melalui organisasi kepada suatu objek atas dasar pengetahuan dan pengalaman seseorang yang sudah terjadi baik itu merupakan pendapat yang baik atau buruk sehingga nantinya akan berpengaruh terhadap objek tersebut.

\section{Teknik Pengumpulan Data}

Data yang penulis kumpulkan terdiri dari dua kategori yaitu data primer dan data sekunder. Untuk mendapatkan data primer yang dibutuhkan, penulis melakukannya dengan dua cara yaitu : Wawancara mendalam (Deap Interview) dan Observasi. Penulis juga memerlukan data sekunder untuk lebih memperkuat lagi fakta-fakta yang ada dalam penelitian ini. Penulis mendapatkan data sekunder melalui internet,artikel atau kliping dan datadata perusahaan yang diteliti.

\section{Unit Analisis}

Unit analisis dalam penelitian ini adalah humas (public relations) Lembaga Penyiaran Publik Televisi Republik Indonesia (LPP TVRI).

\section{Penentuan Key Informan dan Informan}

Jika dikaitkan dengan permasalahan pokok penelitian, penulis menentukan teknik purposive. Penulis mewawancarai Manager Kelembagaan Hukum 
dan Humas sebagai Key Informan, yang berkaitan dengan masalah pokok penelitian, yaitu : Ibu Dra.Meggy Th.Rares (Manager Kelembagaan Hukum dan Humas LPP TVRI) dan staff Humas LPP TVRI, Bapak Nurmaman

\section{Lokasi dan Waktu Penelitian}

Penelitian ini berlokasi di Lembaga Penyiaran Publik (LPP TVRI) JL.Gerbang Pemuda Senayan, Jakarta Selatan. Lamanya penelitian dimulai pada tanggal 10 Oktober 2008 sampai dengan 10 November 2008.

\section{Teknik Analisa Data}

Dalam penyajian dari hasil yang telah diteliti, penulis menggambarkan deskriptif analisis yang didapat yaitu:

1. Berdasarkan informasi yang diperoleh dalam penelitian dari Key Infoman dan Informan yang dilakukan melalui wawancara mendalam akan dianalisis

2. Data yang diperoleh dari masing-masing kategori penulis analisis secara deskriptif

Dari masing-masing kategori tersebut yang telah diperoleh akan dikaitkan antara informasi yang satu dengan informasi yang lain sebagai jawaban.

\section{Hasil Penelitian}

\section{Citra TVRI}

Bagi Lembaga Penyiaran Publik TVRI citra merupakan bagian dari visi dan misi humas yang harus ditingkatkan. Citra bagi TVRI sangat penting karena jika TVRI citranya baik akan di terima dan disukai oleh publik. citra bagi stasiun TVRI. Menurut humas TVRI, citra TVRI saat ini masih baik walaupun 
baiknya kurang maksimal, karenakan kalau kita memasarkan berbagai kalangan, berbagai keinginan, berbagai latar belakang menilai citra sesuai kebutuhannya juga secara relatif .

Namun dari data yang didapat penulis dari lapangan citra LPP TVRI mulai perlahan-lahan mengalami kemerosotan hal ini dikarenakan semakin banyaknya stasiun televisi yang bermunculan langsung disukai oleh pemirsa karena program-program yang disajikan oleh stasiun telesisi swasta yang baru bermunculan ini sangat bagus dan unik serta penerimaan gambarnyapun di masyarakat (kepada penonton) sangat bagus sehingga disukai oleh pemirsa televisi. Citra negatif TVRI yang ada dalam masyarakat adalah tayangan atau program-program acara yang tidak menarik atau dianggap ketinggalan zaman serta masalah teknis TVRI seperti penerimaan gambar yang kurang bagus.

Menanggapi hal tersebut, key informan dan informan menyatakan bahwa saat ini pun TVRI tengah terus memperbaiki kualitas siaran baik isi maupun teknis. Mereka menyikapi kritik itu dengan bijaksana dan dari segi programatis, mencermati kebutuhan publik itu sendiri seperti yang disesuaikan dengan kebutuhan dari publik sendiri. Dari kebutuhan tersebut, hal ini yang dibidik oleh program TVRI itu seperti apa, jadi sesuai keinginan publik mungkin dari berbagai generasi. Mereka juga berterima kasih atas masukan yang ada.

TVRI mempunyai Lembaga Pusat Penelitian dan Pengembangan (pesulitbang) di TVRI semenjak adanya LPP, memang secara keseluruhan dan secara merata keseluruh Indonesia survei mengenai citra TVRI belum pernah dilakukan, namun menurut pesulitbang pernah dilakukan survei di daerah-daerah di kota besar misalnya di Medan, Menado pernah dilakukan dipusat hanya kotanya saja dan kalau menurut suvei pesulitbang sendiri 
didaerah TVRI masih ditonton sekitar 40-60\% didaerah masih menonton TVRI.

Manager humas TVRI masih optimis TVRI masih ditonton atau masih dianggap tapi sebenarnya dalam kalangan tertentu TVRI masih dilirik dan tergantung orangnya yang melihat.

\section{Strategi-Strategi yang Dilakukan Oleh Humas TVRI}

Tugas utama humas TVRI adalah untuk pencitraan, bagaimana lembaga ini bisa dikenal oleh masyarakat dengan memberikan nilai positif, citra positif maksudnya adalah selalu berupaya untuk bisa TVRI dikenal dengan hal yang positif, berbagai macam cara untuk memberikan hal yang positif misalnya bagaimana program-program TVRI "untuk mencerdaskan kehidupan bangsa sesuai dengan misinya" hal itu bisa diterima oleh masyarakat luas untuk semua kalangan. Jadi agar masyarakat dapat melihat TVRI adalah sesuatu instansi yang semestinya itu patut dibanggakan dan dalam hal layar TVRI selalu menjadi pilihan untuk penonton". Caranya adalah dengan Memberikan press realease via fax atau email kepada media-media partner untuk memberitahukan kegiatan-kegiatan, hal-hal apa saja yang dilakukan atau yang terjadi di TVRI agar masyarakat mengetahui TVRI seperti apa adanya, selanjutnya membuat spanduk dan umbul-umbul setiap kali TVRI mengadakan kegiatan-kegiatan atau acara agar masyarakat mengetahui kegiatan TVRI, kemudian mengadakan sosialisasi, dalam status sebagai Lembaga Penyiaran Publik memberikan informasi kepada masyarakat bahwa TVRI sekarang bahwa statusnya seperti ini, seperti mengadakan acara tatap muka dengan pemirsa yang dihadiri oleh berbagai unsur yang ada dimasyarakat agar LPP TVRI dapat lebih dekat dengan masyarakat penonton, disamping itu pimpinan tanpa didampingi dengan humas mendatangi daerah-daerah untuk mensosialisasikan TVRI. 
Media partner TVRI adalah semua media cetak, koran, majalah, tabloid media elektronik seperti Republika, Kompas, Koran Tempo, Suara Pembaruan, Madia Indonesia dan lain-lain pada prinsipnya semua jenis media dapat menjadi partner TVRI .

Sedangkan dalam rangka perbaikan program acara staf humas mengusulkan kepada bagian program agar bisa membuat acara yang bagus walaupun tidak sebagus program-program acara yang lainnya.Dan hasilnya pun disukai oleh kalangan tertentu saja hal ini sudah dapat membuktikan bahwa TVRI masih dapat menyajikan program acara yang bagus. Program-program acara bagi semua penonton setia stasiun TVRI yang akan ditanyangkan sangat menarik dan bervariasi. Sehingga penonton setia TVRI tidak akan jenuh terhadap program-progran TVRI yang terkadang dianggap membosankan atau menjenuhkan.

TVRI sangat berbeda dengan stasiun televisi swasta pada umumnya yang komersil tetapi TVRI tidak dapat demikian walaupun program-program acara yang terdapat di TVRI tidak cukup menarik dibanding mereka tetapi TVRI sudah berhasil mewujudkan misinya menjadi televisi pendidikan untuk mencerdaskan bangsa. Hal inilah yang seharusnya dibanggakan oleh masyarakat.

Selain itu mengganti logo juga diharapkan dapat memperbaiki citra TVRI, dengan mengganti logo TVRI yang lebih berwarna, tidak kaku dan mempunyai makna yang informatif, komunikatif, elegan dan dinamis dalam upaya mewujudkan visi dan misi TVRI sebagai TV Publik yaitu media yang memiliki fungsi kontrol dan perekat sosial untuk memelihara persatuan dan kesatuan bangsa. Makna dari logo TVRI yng melambangkan seperti komet yang bergerak cepat dan terarah serta bermakna gerakan perubahan yang cepat dan terencana menuju televisi publik yang lebih sempurna. Logo terbaru TVRI diharapkan akan membawa perubahan dalam TVRI menjadi 
stasiun TVRI yang diminati oleh para pemirsa dan dapat menampilkan program-program yang ada sebelumnya menjadi lebih baik lagi dan semakin kreatif.

\section{Pembahasan}

Bagi LPP TVRI citra merupakan bagian terpenting untuk dijaga dan diperbaiki jika, citra tersebut tidak baik dimata publik.Citra TVRI dimata humas saat ini bagi humas sendiri baik-baik saja meskipun citra tersebut belum maksimal. Pendapat dari humas TVRI ini merupakan citra cermin (mirror image) karena citra cermin suatu pandangan dari orang dalam perusahaan yang merasa bahwa citra perusahaan tersebut dalam posisi yang baik tanpa mengacuhkan pesan dari orang luar. Sedangkan, menurut pendapat publik yang penulis dapat dari situs internet citra TVRI saat ini dinilai ketinggalan zaman (jadul) dan dari segi teknisnya tidak bagus karena dari segi penerimaan gambar yang dilihat oleh pemirsa tidak bagus. Citra ini dapat dikatakan sebagai citra kini (current image).

Humas TVRI sangat berharap bahwa program-program acara yang ditampilkan oleh TVRI disukai oleh publik sehingga TVRI tidak lagi dikatakan sebagai televisi yang acara-acaranya ketinggalan zaman. Seperti yang diinginkan oleh TVRI, memberikan yang terbaik bagi pemirsanya dalam bentuk program-program acara yang sudah mulai disiarakan. Hal ini masuk kedalam citra keinginan (wish image).

Selain perbaikan kualitas kualitas isi dan teknis tayangan atau program acara, TVRI dalam setiap kesempatan juga sering kali mengadakan acara bakti sosial, hal ini adalah merupakan tanggung jawab sosial yang di lakukan oleh TVRI setiap kali terjadi bencana alam. Dengan begitu citra positif yang akan didapat oleh TVRI. Citra ini merupakan citra perusahaan (corporate image). 
Berikut ini adalah strategi-strategi yang dilakukan oleh humas TVRI dalam memperbaiki citra di mata penonton (publik) yaitu :

1. Strategi komunikasi langsung

Dalam strategi ini humas melakukannya melalui media relations, diantaranya yaitu;

a. press confrence (konfrensi pers)

Dalam press confrence atau jumpa pers dilakukan untuk menyampaikan informasi kepada publik lewat media elektronik maupun media cetak tentang hal-hal yang terjadi didalam TVRI agar publik mengetahui kegitan apa saja yang dilakukan oleh TVRI dalam memanjakan pemirsanya.

b. press realease

Humas TVRI membuat press realease yang disebarkan melalui fax, email, dan mengundang wartawan-wartawan media massa yaitu media elektronik dan media cetak yang sudah lama menjadi partner TVRI.

2.Strategi tindakan

a. Mengusulkan memperbaharui program-program acara yang ada di TVRI dengan menampilkan acara-acara yang menarik, unik dan bagus.

b. Perubahan logo

c. Menganjurkan perbaikan teknis

Mengganti peralatan yang sudah termakan usia dengan yang baru. Hal ini membutuhkan dana yang tidak sedikit, untuk itu perbaikan teknis dilakukan dengan perlahan-lahan. Tidak hanya perbaikan teknis dalam hal peralatan saja tetapi juga dalam setingan studio menjadi lebih menarik lagi.

d. Ikut berpartisipasi dalam kegiatan bakti sosial dalam berbagai kesempatan sebagai bentuk tanggung jawab sosial perusahaan.

Dalam membuat strategi humas TVRI melakukan langkah atau tahapan strategi komunikasi yaitu : 
1. Humas TVRI menetapkan terlebih dahulu siapa sasaran programnya baik sasaran program acara atau siaran maupun kegiatan humas lainnya komunikasi yang terjadi dapat berjalan dengan baik. Sehingga TVRI dapat mengetahui apa yang di butuhkan oleh publik.

2. Humas TVRI menyusun pesan, Strategi yang dipakai adalah strategi of publicity dan strategi of image. Sedangkan Metode yang digunakan oleh humas TVRI pada saat ini adalah metode informatif karena TVRI memberikan informasi kepada publik tentang yang terjadi di dalam negara ini dan memberikan pelajaran-pelajaran yang sangat berguna bagi pemirsanya karena TVRI sudah menjadi televisi pendidikan.

3. Media yang digunakan oleh TVRI adalah media antar pribadi seperti telpon dan surat untuk melakukan komunikasi antar karyawan dan media massa seperti surat kabar, majalah, televisi dan film untuk melakukan dan menyampaikan infomasi kepada publik atau pemirsa TVRI.

Humas TVRI mempunyai beberapa strategi dalam melakukan pendekatan terhadap publik, yaitu :

a. Pendekatan strategi operasional, pihak humas dalam membuat programnya bersikap atau berkemampuan untuk mendengar (listening), dan bukan sekedar mendengar (hear) mengenai aspirasi yang ada di dalam masyarakat, baik mengenai etika, moral maupun nilai-nilai kemasyarakatan yang dianut. Dengan membuka kesempatan menerima setiap saran maupun kritik yang berkaitan dengan kualitas isi maupun teknis siaran.

b. Pendekatan persuasif dan edukatif, TVRI menampilkan program acara untuk mencerdaskan kehidupan bangsa yang sesuai dengan misi TVRI. Jadi agar masyarakat dapat melihat TVRI adalah sebuah instansi yang semestinya itu patut dibanggakan dan selalu menjadi pilihan untuk 
penonton. Dengan demikian, tugas humas TVRI ini menjadi pendekatan persuasif dan edukatif karena dengan menyebarkan informasi dari organisasi kepada publik yang bersifat mendidik.

Pendekatan kerjasama, LPP TVRI selalu berupaya menjaga hubungan baik dengan partner-partner TVRI dari berbagai media massa baik itu dari media elektronik ataupun media cetak. Selain itu TVRI juga menjaga hubungan yang baik pemirsanya yang pada setiap ada kesempatan TVRI mengadakan acara yang bersifat kekeluargaan seperti sewaktu mengadakan HUT TVRI yang disiarkan langsung dari TVRI dengan mengundang pemirsa TVRI untuk datang dan menyaksikan langsung di stasiun TVRI. TVRI juga menjaga hubungan baik antar karyawan yang bisanya diwujudkan dengan mengadakan buka puasa bersama pada setiap bulan ramadhan atau berbagai kegiatan lain. Inilah yang menjadi pendekatan kerja sama.

c. Pendekatan Tanggung jawab sosial, yakni dengan ikut berpartisipasi dalam kegiatan bakti sosial dalam berbagai kesempatan

\section{Kesimpulan}

Kesimpulan yang penulis dapat bahwa strategi yang di gunakan oleh Humas TVRI dalam rangka memperbaiki citra TVRI tehadap dua bentuk strategi yaitu strategi komunikasi (penyampaian informasi) dan strategi tindakan. Strategi komunikasi dilakukan dalam melalui media relations dalam bentuk press confrence, press realease, sedangkan strategi tindakan yaitu perbaikan teknis, perubahan logo, bakti sosial (baksos), membuat program acara yang semenarik mungkin. Dengan metode atau pendekatan yang bersifat informatif, edukatif, operasional dan tanggung jawab sosial.

\section{DAFTAR PUSTAKA}


Arifin, Anwar, Ilmu Komunikasi, PT.Raja Grafindo Persada, Jakatra, 2003

Abdurachman, Oemi. Dasar-dasar Public Relations. Bandung: PT. Citra Aditya Bakti, 2001

Jefkins, Frank, and Daniel Yadin Public Relations, Jakarta:Penerbit Erlangga, 2004

Manajemen Public Relations dan Media Komunikasi, PT. Raja Grafundo Persada, Jakarta, 1998

Kiat dan Strategi Kampanye Public Relations, Rajawali Pers, Jakarta, 2000

Metode Public Relations dan Komunikasi, PT. Raja Grafindo Persada, Jakarta, 2003

Kiat dan Strategi Kampanye Public Relations, PT. Raja Grafindo Persada, Jakarta, 2007

Rusalan, Rosady, Manajemen Public Relations dan Manajemen Komunikasi Konsepsi dan Aplikasi, PT. Raja Grafindo Persada, Jakarta, 1997

Soemirat, Soleh dan Elvinaro Ardianto, Dasar-Dasar Public Relations, PT. Remaja Rosdakarya, Bandung, 2004

Vardiansyah, Dani, Pengantar Ilmu Komunikasi, PT. Ghalia Indonesia, Bogor, 2004

Wasesa, Silih Agung, Strategi Public Relations, PT. Gramedia Pustaka Utama, Jakarta, 2006

Zulkarmein, Pengantar Komunikasi Pembangunan, PT. Remaja Rosdakarya, Bandung, 1998 